\title{
Review
}

\section{An impossible dream? Racial integration in the United States}

\author{
Sharon A. Stanley (ed.) \\ Oxford University Press, 2017, 210 pp., \\ ISBN: 978-0190639976
}

Contemporary Political Theory (2019) 18, S1-S4. https://doi.org/10.1057/s41296-0170162-7; published online 5 October 2017

At a time when the United States is experiencing levels of racial tension not seen since the Civil Rights era, when white nationalism and explicit white supremacism have re-emerged in the public sphere, and when de facto racial segregation still structures daily life in many U.S. cities, a frank and realistic reappraisal of racial integration is much needed. This is precisely what Stanley's book provides, defending a complex ideal of racial integration while taking seriously (and ultimately also vindicating) the reasons for integration pessimism and resistance. If this sounds contradictory, it is only because I have not yet mentioned what is perhaps the most provocative thesis of the book: the idea that the moral imperative to pursue integration itself falls differentially on Americans depending on their racial identity. In spite of decades of standpoint theory and research emphasizing the importance of racial positionality, it is still commonly assumed - both in popular discourse and within the academy - that whatever moral obligations arise from serious consideration of racial injustice arise equally for all, regardless of one's position within the U.S. racial order. Indeed, this assumption structures what is perhaps the most ambitious philosophical defense of integration in recent memory, Elizabeth Anderson's The Imperative of Integration (2010), a book which acts as the foil against which Stanley presents her own ideal of integration. By contrast with Anderson, Stanley argues that while real integration would surely involve 'mutual transformation' among black and white Americans, the obligation for black Americans to pursue integration is dependent upon white Americans acknowledging and relinquishing their white privilege, and that obligation on the part of white Americans is not similarly dependent. In the language of Kantian moral theory, we might say that whites' moral obligation is categorical, grounded in the demands of justice, while blacks' obligation is merely hypothetical, resting, Stanley argues, on empirical judgments about the likelihood of success, the potential costs of failure, and the genuineness of white relinquishment. This moral asymmetry is the theoretical backbone of the book, and demands the attention of

(c) 2017 Macmillan Publishers Ltd. 1470-8914 Contemporary Political Theory Vol. 18, S1, S1-S4 
not only political theorists, but ethical theorists as well, who often neglect the situational and political contexts that shape moral obligation.

Since white acknowledgement and relinquishment of racial privilege is presented as the lynchpin of successful integration, it follows that optimism about the success of integration measures rises or falls with the estimation of the likelihood of this sort of mass moral conversion, and on this point Stanley is decidedly pessimistic. In her chapter 'Confronting White Privilege,' Stanley draws upon current empirical research to describe the extreme resistance on the part of most whites to even acknowledging white privilege - let alone making the sorts of sacrifices that would amount to a good-faith attempt to relinquish it. Such sacrifices would be both psychic - the so-called 'psychological wage' of whiteness first identified by Du Bois - and material - the concrete loss of ill-gotten gains in employment, education, income, home ownership, etc. Still, the claim that genuine integration is unlikely in the current political climate is distinct from the claim that it is an intrinsically flawed goal. Stanley rejects the latter claim, and endeavors to develop an ideal of integration to which, she argues, even its most important critics could assent.

This ideal of integration would require concrete measures aimed at redistributing power more equally among black and white communities. These measures include reparations, the reorganization and strengthening of regional forms of governance in black urban communities, and criminal justice reform to address the racially disproportionate character of mass incarceration. Stanley's discussion of reparations is especially interesting. She argues that reparations should be conceived not as a response to slavery, as is often assumed, but rather as recompense for a less distant harm that is more directly traceable to contemporary black disadvantage: the housing and lending discrimination directly responsible for the existence of black urban ghettos. Correspondingly, she conceives of the primary goal of reparations (and to some extent the other two measures as well) as 'dismantl[ing] the urban ghetto,' which would in turn reduce the material deprivation and inequality that characterize life in these neighborhoods (p. 86). Without offering a full-blown theory of how reparations would be structured, she nonetheless suggests that funds be filtered through organizations that pursue such a goal, in lieu of individual cash payments. Similarly, her reflections on 'metropolitan regionalism' aim to correct the current imbalance of power between urban black communities and surrounding white suburbs through the reorganization and even elimination of municipal boundaries. The central goal here is to give black communities a voice in regional issues that potentially disadvantage them, from restrictive zoning laws to transportation and education policy. If reparations is a primarily economic initiative, then metropolitan regionalism is a specifically political one. 'When black votes matter,' Stanley asserts, 'black voices must be attended' (p. 92). Finally, the demand for reforming an unjust criminal justice system pursues both economic and political ends, as mass incarceration involves both economic harm and political 
disenfranchisement. Here Stanley follows Michelle Anderson's work on mass incarceration (2012), as well as Kahlil Gibran Muhammed's historical analysis of the association between blackness and criminality (2011). All of these measures are necessary, Stanley argues, to dismantle the complex system that continues to keep black Americans not only separate from, but subordinate to white Americans.

This discussion of the necessary conditions of defensible integration, however, only reminds the reader of the centrality of the previously discussed psychological dimensions of the proposed social transformation. This is because what emerges from this analysis, according to Stanley, is what she calls a 'temporal paradox' of integration. She draws upon a critical survey of research on the 'contact hypothesis' - the theory that increased contact between members of different racial groups can, under conditions of equality, reduce prejudice. The qualification 'under conditions of equality' is key, Stanley argues, to understanding the paradox. For, in order to realize the concrete policies that she identifies as preconditions of successful integration, whites would already have to have gained the benefits of that very integration, in the form of increased interracial solidarity, reduced prejudice, and so on, and blacks would already have to have achieved the political gains necessary to have an effective political voice. Thus, integration appears as both cause and effect of white relinquishment and interracial solidarity, and of black political empowerment, and Stanley sees no obvious way out of this paradoxical circularity. Perhaps this is part of the reason why she defends black integration pessimism, and acknowledges the value of intra-racial solidarity and affiliation even under conditions of successful integration, which she views as always a process, and never a fait accompli.

It is somewhat surprising that a book that hangs so much on the possibility of white psychic transformation draws so little from empirical psychological research on the nature of racial prejudice and the nature of moral persuasion and conversion. Stanley does discuss white psychic transformation extensively - in the chapter entitled 'How to Integrate: Hearts and Minds' and the aforementioned chapter on 'Confronting White Privilege.' But these chapters focus more on documenting the depth and breadth of white resistance to integration and racial equality, both historically and in the present, and less on the psychological mechanisms underlying such resistance, or the features of human psychology that might hold some promise for a future moral conversion. I am thinking, for example, of the wealth of research on empathy, or the research into the sorts of cognitive biases attribution bias, system justification bias, etc. - that undergird the failure to acknowledge racial injustice. This would surely be a book unto itself, and so perhaps it is not fair to expect Stanley to include a complete account of this sort in her already ambitious analysis. But it does seem that the question mark in Stanley's title could only be dispensed with by including an analysis of this sort. As it stands, the book ends without truly answering its motivating question. Stanley only notes that integration pessimism never fully closes the door on true integration: 'it is 
simply to say "not now, we are not ready yet" (p. 188). The burden of achieving the complex and admirable ideal Stanley lays out in the book is placed squarely on white shoulders, and Stanley offers no ultimate predication as to 'how they will shoulder that burden.'

Yet even without providing an answer to its central question, the book still provides much value. Defenses of integration often proceed from the assumption that blacks have much to gain from it. But it is also true that blacks have much to lose from integration done poorly, and Stanley's account proceeds from this important insight, without abandoning integration as a worthy goal.

\section{References}

Alexander, M. (2012) The New Jim Crow: Mass Incarceration in the Age of Colorblindness. New York: The New Press.

Anderson, A. (2010) The Imperative of Integration. Princeton, NJ: Princeton University Press.

Muhammed, K.G. (2011) The Condemnation of Blackness: Race, Crime, and the Making of Urban America. Cambridge, MA: Harvard University Press.

Andrew J. Pierce

Saint Mary's College, Notre Dame, IN 46556, USA apierce@saintmarys.edu 